IZA DP No. 7665

UK Migration Policy and Migration from Eastern Partnership Countries

Ken Clark

Stephen Drinkwater

October 2013 


\title{
UK Migration Policy and Migration from Eastern Partnership Countries
}

\author{
Ken Clark \\ University of Manchester \\ and IZA \\ Stephen Drinkwater \\ Swansea University \\ and IZA
}

Discussion Paper No. 7665

October 2013

\author{
IZA \\ P.O. Box 7240 \\ 53072 Bonn \\ Germany \\ Phone: $+49-228-3894-0$ \\ Fax: +49-228-3894-180 \\ E-mail: iza@iza.org
}

\begin{abstract}
Any opinions expressed here are those of the author(s) and not those of IZA. Research published in this series may include views on policy, but the institute itself takes no institutional policy positions. The IZA research network is committed to the IZA Guiding Principles of Research Integrity.

The Institute for the Study of Labor (IZA) in Bonn is a local and virtual international research center and a place of communication between science, politics and business. IZA is an independent nonprofit organization supported by Deutsche Post Foundation. The center is associated with the University of Bonn and offers a stimulating research environment through its international network, workshops and conferences, data service, project support, research visits and doctoral program. IZA engages in (i) original and internationally competitive research in all fields of labor economics, (ii) development of policy concepts, and (iii) dissemination of research results and concepts to the interested public.
\end{abstract}

IZA Discussion Papers often represent preliminary work and are circulated to encourage discussion. Citation of such a paper should account for its provisional character. A revised version may be available directly from the author. 


\section{ABSTRACT}

\section{UK Migration Policy and Migration from Eastern Partnership Countries}

This paper examines UK migration policy and recent migration flows from Eastern Partnership (EaP) countries to the UK. Although inflows of migrant workers were relatively large in the mid-2000s, especially amongst Ukrainians, these have fallen following changes to UK immigration policy, especially the Seasonal Agricultural Workers Scheme and the introduction of the Points Based System. As a result, the stock of migrants from EaP countries resident in the UK is small, especially in comparison to migrants from the new member states that joined the EU in 2004 (EUA8 countries). Migrants from the EaP countries also have an older age profile then EUA8 migrants. Employment rates are lower for migrants from EaP countries but they have fairly similar occupational attainment to other European migrants. This may be due to the high average levels of education amongst migrants since a relatively large proportion of migrants to the UK from EaP countries are highly educated. The paper is completed by a discussion of the skill needs of the UK economy. Our conclusions suggest that despite there being scope for increased migration from the EaP countries to help fill skill gaps, it seems very unlikely that the UK will allow large numbers of migrants from the EaP countries to enter the UK in the near future. This is because of the continued sluggish performance of the UK economy and the attitudes towards (increased) immigration displayed by political parties/the current government, as well as the general public.

JEL Classification: J61, F22

Keywords: migration, Eastern Partnership Countries, United Kingdom, labour market

Corresponding author:

Ken Clark

Economics, School of Social Sciences

University of Manchester

Manchester, M13 9PL

United Kingdom

E-mail:ken.clark@manchester.ac.uk

\footnotetext{
* This study was conducted under the project entitled "Costs and Benefits of Labour Mobility between the EU and the Eastern Partnership Countries" for the European Commission (Contract No. 2011/270312, tender procedure EuropeAid/130215/C/SER/Multi). The European Commission retains ownership of the materials contained herein.

Material from the Quarterly Labour Force Survey is Crown Copyright and has been made available by the Office for National Statistics (ONS) through the Economic and Social Data Service. We are also grateful to comments on an earlier draft from Martin Kahanec and Lucia Kurekova. The views expressed in this study and any errors therein are those of the authors.
} 


\section{Introduction}

The United Kingdom (UK) has a long history of receiving large numbers of migrant workers. In particular, successive cohorts of immigrants from former Commonwealth colonies, especially in the West Indies and the Indian sub-continent, started arriving at the end of the 1940s (Hatton and Wheatley Price, 2005). Many of these migrant workers took up positions in sectors experiencing labour shortages, such as transport, the National Health Service and other public services, and selfemployment was also an important form of activity for some of the migrant groups (Clark and Drinkwater, 1998). Over the last decade, however, the UK has also become one of the main destination countries for immigrants from various parts of Europe. For example, data on National Insurance Numbers issued to overseas nationals (NINos) indicate that there was a five-fold increase in the number of "new" immigrant workers arriving in the UK from European countries between 2002 and 2007, rising from around 103,000 to over $500,000 .{ }^{1}$ As a result, the percentage of NINo registrations made by Europeans almost doubled, rising from 33 per cent to 63 per cent over this period. ${ }^{2}$ Much of this increase can be explained by the migration that followed the enlargement of the European Union in May 2004, since the UK was one of only three member states at the time to open their border to migrant workers from the new member states in Central and Eastern Europe. ${ }^{3}$ Although the number of NINo registrations made by Europeans has fallen since the start of the recession, it stood at 342,000 in 2010 and continued to account for over a half of the total NINo registrations made in the UK that year.

In addition to the migration flows that have followed enlargement of the European Union, there have also been important changes over the last decade in policy in the UK towards immigrants from outside the European Economic Area (EEA). In particular, the overall thrust of immigration policy in the UK since 2005 has been to restrict entry by non-EEA workers to skilled occupations. The main change was the introduction of the Points Based System (PBS), which began in 2008 to regulate inflows of immigrant workers from outside the EEA. The PBS consolidated in excess of 80 work and study routes into the UK, which included the Highly Skilled Migrant Programme and Work Permits, into five main tiers and replaced the previous system of immigration (Devitt, 2012). These five tiers relate to highly skilled migrants, medium and highly skilled migrants with a job offer, quota 
based low-skilled schemes to fill temporary labour shortages, students and youth mobility and temporary workers.

Changes have also occurred to two low-skilled schemes, which lie outside the PBS. These are the Seasonal Agricultural Workers Scheme (SAWS) and the Sector Based Schemes (SBS). These are now targeted exclusively at Bulgarian and Romanian nationals and allow them to enter the UK for up to six months to work in the agricultural sector: planting, harvesting or processing food and handling livestock. A strict quota of permits is issued each year - the quota was just over 20,000 in 2011. However, prior to the accession of Bulgaria and Romania to the European Union in 2007, these schemes had been open to migrants from other countries. Large numbers of Ukrainians, Belarusians and Moldovans were employed on these schemes in the mid-2000s, especially on the SAWS. ${ }^{4}$ For example, Salt (2009) reports that Ukrainians accounted for 33 per cent of the 16,127 workers on the SAWS and 38 per cent of the 3,586 workers on the SBS in 2006. In 2004, there were 2,258 workers from Belarus registered on the SAWS and more than 1,000 Moldovans were on the same scheme in each year between 2005 and 2007. Therefore, the changes in immigration policy that have occurred in the UK over the last decade are of particular importance to Eastern Partnership (EaP) countries because potential migrant workers to the UK from these countries are not able to benefit from the freedom of movement enjoyed by individuals from the European Union, including from the member states that joined in 2004 and neither can younger migrants from EaP countries now enter the UK on the SAWS or SBS. In addition to impacting on the size of migration flows from EaP countries, these policy changes are likely to have had an effect on the composition of migrant workers. For example, migration flows from EaP countries are likely to have become less dominated by the youngest age groups and biased more towards women and highly educated individuals.

The changes in migration flows and in immigration policy should also be considered with reference to the UK's economy, which was in a healthy position from 2000 up until 2007. This period produced average growth rates of 2.75 per cent per annum and annual unemployment rates of around 5 per cent. However, since the start of the global financial crisis in late 2007, the economy has deteriorated considerably. The UK was officially in recession in 2008 and 2009, with Gross Domestic Product (GDP) falling by around 6 per cent (Gregg and Wadsworth, 
2010). ${ }^{5}$ As a result of the poor state of the economy, unemployment has increased and has hovered around 8 per cent in recent years. Very high levels of youth unemployment are a major concern (Blanchflower and Bell, 2010), with the unemployment rate for 16 and 17 year olds at almost 40 per cent, and that for 18-24 year olds at 20 per cent. Given that immigrants are thought to compete with younger native-born workers for jobs and that employment levels amongst immigrants have continued to rise - while falling for the native-born (ONS, 2012) - then public attitudes towards immigration in the UK tend to be quite negative. For example, Blinder (2011) reports evidence from cross-national survey data (Transatlantic Trends 2010) to suggest that people from the UK have more negative views towards immigrants than people from other Western countries. In particular, the percentage of respondents reporting that "there are too many immigrants" and "immigration is more a problem than an opportunity" was higher in the UK than it was in France, Germany, Italy, Spain and the United States. Furthermore, there is now greater opposition to immigration amongst political parties in the UK, as demonstrated by the coalition government's commitment to reduce net migration from hundreds of thousands to "tens of thousands".

This paper is organised in the following manner. The next section contains a discussion of recent inflows of migrant workers from $\mathrm{EaP}$ countries to the UK, along with some information on the stocks of migrants from these countries. Section 3 focuses on the demographic characteristics of migrants from EaP countries, mainly using the Labour Force Survey (LFS). The use of this dataset also enables similar information to be provided on comparison groups of migrants in the UK. Section 4 again uses LFS data to examine the labour market characteristics of the same groups

that are analysed in Section 3. A labour market impact assessment is undertaken in Section 5 by firstly discussing issues connected to the implications of migration flows to the UK as well as on the skill needs of the UK's labour market. Some concluding comments can then be found in the final section, especially in relation to policy implications.

\section{Flows of Migrants from EaP Countries to the UK and Migrant Stocks}

Inflows of migrants from EaP countries are mainly examined using administrative data published by the Home Office. The data identify passengers given leave to enter 
for several different reasons: employment, study, family and other. Information is available on these categories between 2004 and 2010. The main focus is on individuals given leave to enter the UK for employment purposes but aggregate information on all passengers arriving from the six EaP countries is reported in Table A1 in the Appendix. Table A1 also shows the total number of passengers from all EaP countries and the bottom row expresses this figure as percentage of total passengers. The table suggests that although the total number of passengers to the UK from EaP countries has increased by over a third between 2004 and 2010, they only account for a very small proportion of total passengers to the UK. In 2004, only 0.7 per cent of passengers of all nationalities came from $\mathrm{EaP}$ countries, rising to 1.0 per cent in 2010. Around 60 per cent of EaP passengers in each year came from the Ukraine, with around 15 per cent from Belarus and around 9 per cent from Azerbaijan.

The breakdown in the number of passengers into its four constituent categories is shown in Table A2 in the Appendix for EaP countries and for all nationalities. However, the vast majority of passengers to the UK are in the "Other" category. This category mainly consists of "visitors", and includes both ordinary and business visitors, as well as people returning from a temporary absence abroad and passengers in transit. Following the "Other" category, employment is the next most important category for passengers given leave to enter the UK for individuals from $\mathrm{EaP}$ countries. However, the numbers entering via this route have fallen for this group of countries, especially since 2007. In contrast, the number of people entering the UK via the study route has increased by over 1,000 since 2005 but EaP countries still only account for less than 1 per cent of the total number of student visas issued. The family category is the smallest, with only a total of 435 individuals from EaP countries entering the UK on this type of visa in 2010.

Figure 1 clearly shows the trend in the numbers of migrants from EaP countries entering the UK through the employment route between 2004 and 2010. The large falls in the volume of migrant workers arriving from the Ukraine is particularly noticeable after 2006. The change between 2007 and 2008 was especially large, since employment visas issued to Ukrainians fell from over 5,000 to just above 1,000. Workers given leave to enter from Belarus and Moldova also showed a sharp decline after 2007. The most important factor in explaining the falling numbers arriving in the UK from these countries appears to be the reduction in employment on the SAWS. It may also be partly explained by the changes brought 
about after the introduction of the PBS as well as the recession. The role of these influences will be discussed with reference to the following tables. Changes in the number of employment visas issued to Armenian, Azerbaijani and Georgian nationals are much smaller because the levels at the start of the period were far lower. Table A2 does, however, show these changes and indicates that the number migrants from Armenia and Georgia entering the UK via the employment route fell by more than half between 2004 and 2010, but there has been an increase amongst Azerbaijani migrants. For example, 100 employment visas were issued to Azerbaijani migrants in 2005 but this rose to 220 in 2009 before falling back to 195 in 2010.

The changes in the number of people entering through the employment route can be further investigated by splitting the work category into pre- and post-PBS periods and also into different types of work categories. Table 1 reports information in the pre-PBS period (2004-2007) and shows that the number of work permits issued in 2007 declined sharply, especially to Ukrainians since only around half the amount were issued in this year compared to 2005. However, there is also a fall of around 1,000 in the number of Ukrainians in the other category in 2007, which is the result of the changes in terms of eligibility made to the SAWS and SBS. Large falls in this category are also observed for Belarusians, with a decline of over 1,000 (63 per cent) in 2007 compared to 2004. In contrast, the number of Moldovans in the "other" category remained fairly constant between 2005 and 2007, following the large rise seen between 2004 and 2005. ${ }^{6}$

Information on EaP migrant workers entering the UK in the PBS period (2008-2010) is shown in Table 2. This splits migrants entering via the employment route into three broad groups: the PBS categories, the pre-PBS categories and dependents (which combines those entering both through the pre-PBS and PBS routes). Employment entrants from EaP countries continued to arrive in the UK through pre-PBS categories in 2008, although the numbers were far lower than in the pre-PBS period since only 1,545 migrants from EaP countries entered in 2008, compared to more than 9,000 in 2007 - as indicated in Table 1. Only 30 migrants from $\mathrm{EaP}$ countries came through the PBS routes in 2008 but this rose to 815 in 2010 , with Ukrainians accounting for over 60 per cent of this figure.

Further information on migrant workers from EaP countries who entered the UK in the pre-PBS and PBS periods is presented in Tables A3 and A4 of the Appendix. Table A3 shows that work permits were still fairly important in 2008, 
especially for Ukrainians but declined rapidly in the two subsequent years and very few were issued in 2010, since fewer than 15 migrant workers from EaP countries entered on work permits. The table also reveals that the majority of dependents entering in this period via employment did not come through the PBS route. The reduction in the amount of entrants from EaP countries through other pre-PBS employment routes in 2008 to 2010 was particularly noticeable compared to previous years since these totalled fewer than 250 in each of the three years, whereas Table 1 indicates that the equivalent number for 2004 had been over 7,000 and was still over 5,500 in 2007. This again demonstrates how the changes made to the SAWS and SBS have affected the number of migrant workers from EaP countries entering the UK.

Table A4 presents details on employment entrants from EaP countries in the PBS period for the PBS work categories. Tier 2 (skilled workers) is the main employment route into the UK for EaP migrants and, to satisfy the points requirement, prospective employees from $\mathrm{EaP}$ countries had to demonstrate that they were suitably skilled, had adequate funds to maintain themselves and could speak English to the required standard (equivalent to level B1 on the Common European Framework of Reference). In addition, they would require sponsorship by an employer in the UK, which would include stipulations on the employer to ensure that the occupation was on the list of shortage occupations and that appropriate opportunities had been given to workers from the European Union to apply for the job in question. Tier 1 is for "high-value" migrants and the requirements for entry through this route have gradually been tightened since the PBS was introduced. At present, only those deemed to have "exceptional talent" or who have over $£ 1$ million to invest in the UK or who are entrepreneurs are able to enter via this channel. Tier 5 is currently for temporary workers in particular areas such as creative and sporting professions or religious and charity workers.

Table A4 shows that very few migrant workers from EaP countries entered via the new tiers in 2008 but this rose in 2009 and 2010. This was particularly the case for Tier 2 workers, since the number of Tier 1 entrants fell back slightly in 2010 compared to 2009. Around half of Tier 1 and 2 entrants in each year were Ukrainian, although the number of Azerbaijani migrant workers entering through these routes in 2009 and 2010 was also relatively high. Migration through the Tier 5 (temporary migration) route also increased in 2009 and 2010, and was again concentrated 
amongst Ukrainians. However, it is very small in comparison to other employment category in the pre-PBS period.

Flow data on migrants to the UK are also available from the NINo database, maintained by the Department of Work and Pensions. This again is an administrative database which contains information on overseas nationals registering for a national insurance number in the UK. The majority of the individuals in this database have already taken up or are about to take up employment in the UK, but it does also contain people claiming certain benefits. This should, therefore, represent a relatively accurate record of new migrant workers entering the UK for the first time (Drinkwater et al., 2010). The data are available from the start of 2002 up until the third quarter of 2011, which is the latest information available at the time of writing. The information can be split by calendar or financial year of registration. Figure 2 provides information on overall flows from EaP countries. This figure confirms the trends shown in Figure 1, but the reductions are not as sharp. For example, the number of NINo registrations by Ukrainians falls from an average of around 2,000 in 2004-2007 to around 1,200 in 2008-2010. Therefore it does not capture the majority of migrant workers from EaP countries employed on the SAWS and SBS but will include migrants entering on work permits or via the PBS categories. It also includes the self-employed as well as some benefit claimants.

Table 3 presents some additional information from the NINo database by reporting the total number of registrations in the UK, the total number of registrations from $\mathrm{EaP}$ countries, the percentage of registrants from $\mathrm{EaP}$ countries who are Ukrainian and the percentage of total registrants from EaP countries in each year between 2002 and 2011. The table indicates that the total number of NINo registrations from EaP countries peaked in 2007 at 3,860, which was the same year as total NINo registrations reached a peak. However in that year, EaP nationals accounted for less than 0.5 per cent of total NINo registrations in the UK. This percentage was highest in 2004, when 0.83 per cent of all NINo registrations were made by EaP nationals. This percentage has declined since then, falling to under 0.4 per cent in each year since 2007. More than half of NINo registrations from EaP countries in each year were made by Ukrainian nationals. This percentage was highest in 2002, at just over 62 per cent, and lowest in 2009, when Ukrainians accounted for 51.7 per cent of NINo registrations from EaP countries. Analysis of NINo data by country of nationality reveals that migration flows are influenced by 
economic factors in the home country. In particular, fluctuations in growth and unemployment rates in some countries impact on migration flows to the UK in accordance with the predictions of economic theory, including increased recent inflows from Spain, Greece, Italy, Ireland and Portugal to the UK. However for EaP countries, variations in NINo registrations in recent years appear to have been largely driven by migration policy, especially the changes made to the SBS and SAWS.

The latest Population Census took place in the UK in March 2011. However, not all data have been released for the different parts of the UK. 7 The most recent Census information on country of birth for the whole of the UK relates to 2001 and this tends to be aggregated, apart from large countries. ${ }^{8}$ For example, information on the stock of foreign-born residents from Eastern European countries has been grouped into a single category, apart from Poland. Therefore, in order to obtain estimates of people born in countries with a small resident population in the UK in 2001, it is necessary to commission a table from the relevant national statistical agencies. However, in the country of birth database produced by OECD (2008), the resident population in the UK in 2001 is based on Census returns in different parts of the country. This information is presented in Table 4 and indicates that individuals born in the Ukraine accounted for 78 per cent of the total number of immigrants from EaP countries residing in the UK in 2001. However, people born in EaP countries only accounted for a very small percentage of not just the total population of the UK (less than 0.03 per cent) but also the immigrant population ( 0.31 per cent). Furthermore, Ukrainians only accounted for 0.24 per cent) of the UK immigrant population in 2001. The equivalent percentage for those born in all other EaP countries was just 0.07 per cent. Apart from Ukraine, the only other EaP country that had a resident population in excess of a 1,000 was Belarus - twice the number for the four remaining EaP countries.

According to the 2011 Census for England and Wales, there has been an increase in resident migrants from all six EaP countries. The estimated number of people born in Ukraine living in England and Wales in March 2011 was 20,700. This represents a fairly large increase in the stock of migrants over the 2001 figure for the UK as a whole (under 12,000), as shown in Table 4. Similarly, the estimated number of migrants from other EaP countries living in England and Wales had also risen 
quite substantially, and stood at 14,438 in 2011 (1,638 from Armenia, 2,641 from Azerbaijan, 4,133 from Belarus, 3,015 from Georgia and 3,011 from Moldova). However, migrants from all EaP countries still only accounted for $0.47 \%$ of all migrants in England and Wales in 2011.

Other recent estimates on the stock of immigrants from different countries of birth have been published by the ONS (2010) using the Annual Population Survey (APS). This is a representative sample of around 325,000 individuals that is used to obtain regular estimates of the population and their characteristics by applying population weights to the survey data. It includes information from the LFS, which in itself is too small to obtain estimates on particular demographic groups or areas, but the APS contains a boost to the regular LFS sample. ${ }^{9}$ ONS (2010) report estimates of immigrants from the APS for J anuary to December 2010 from the top 60 countries in terms of where they were born. These estimates suggest that the resident stock of immigrants from each of the EaP countries was fewer than 20,000 in 2010, since the country that was $60^{\text {th }}$ in the rankings - the Republic of Korea - had an estimated population of 21,000.10 The small populations from EaP countries can be confirmed by referring to the microdata for the same period, with the estimated stock of Ukrainians in the UK totalling around 16,000 in 2010, whilst the combined estimated population from the rest of the EaP countries was fewer than 11,000.11

Given the relatively small estimated populations from EaP countries in the UK, despite the relatively large inflows from some EaP countries in the mid-2000s highlighted in Figures 1 and 2, this would suggest that a fairly high proportion of the migrant workers arriving in the UK from EaP countries have subsequently left. This is certainly likely to be true of workers who were employed on the SAWS and SBS. There are only a few studies on return migration from the UK. Dustmann and Weiss (2007) use the LFS to examine return migration for a composite group of immigrants to the UK but their sample only covers the period 1992-2002. Pollard et al. (2008) estimate that perhaps half of post-enlargement EUA8 migrants had returned to their home countries between 2004 and 2007. This may provide some indication of the propensity for return migration amongst people from EaP countries, although EUA8 migrants are able to come to back to the UK to work without restriction, which is not the case for migrants from $\mathrm{EaP}$ countries. 


\section{Demographic Characteristics of Migrants from EaP Countries to}

\section{the UK}

This section is based on the analysis of data from the Quarterly LFS. The dataset used to examine the demographic characteristics of migrants from EaP countries resident in the UK has been constructed by merging (52) successive quarters of LFS data. In particular, information from the first quarter of 1999 has been combined with files up to the fourth quarter of 2011. This has been done because of the small number of observations in any one quarter, and identifiers for migrants from all EaP countries have only been included in the LFS from the start of 1999. Migrants from EaP countries have been defined according to their country of birth. ${ }^{12}$ To prevent double-counting, only those respondents in their first wave of interview are included in the dataset. ${ }^{13}$ Drinkwater et al. (2009) contains further details on using the pooled LFS data to examine the demographic characteristics of immigrants from groups of countries. Given sample sizes, there is a need to combine the EaP countries together (with Ukraine and other EaP countries the most disaggregated split that is generally possible). Comparisons are made with other European migrants (these groups are the EU14; EUA8 and Other Europeans).

In order to initially examine the characteristics in the sample of migrants from $\mathrm{EaP}$ countries, Table 5 contains information on just gender and age, the latter just split according to whether the individual is of working age. The table shows that a slight majority of migrants from $\mathrm{EaP}$ countries in the sample are male. There are some differences between countries, with this percentage varying from 46.2 per cent amongst Belarusian migrants to 51.4 per cent for migrants born in the Ukraine. However, the total number of observations in the sample for migrants from Belarus is small. The table also reveals the relatively high percentage of Ukrainian migrants who are not of working age since only around 57 per cent of this group are aged between 16 and 59 for women and 16 and 64 for men. ${ }^{14}$ In contrast, over 80 per cent of non-Ukrainian migrants from EaP countries in the sample are of working age. The reason why a relatively low percentage of Ukrainian migrants are of working age is because 36 per cent of this group are aged 65 or over. This is the result of the high percentage arriving in the UK before 1990 (37 per cent, compared with 5 per cent of migrants from other EaP countries). 
Given the small number of observations of working age migrants from individual EaP countries other than the Ukraine in the sample (just 112 in total), the three categories of non-Ukrainian migrants reported in Table 6 have been combined for the analysis in the remainder of this section. In addition to the two categories for migrants from EaP countries (Ukraine and Other EaP countries), information is also provided for three other groups of European migrants of working age: those born in the EUA8, EU14 and Other Europe. ${ }^{15}$ Table 6 provides details on the gender and age of working-age migrants for all five groups. The statistics on gender accord with the information provided in the NINo database, which shows that recent migration flows from EaP countries have been dominated by women, since around 60 per cent of working-age migrants from EaP countries are female and is particularly high for Ukrainians. This implies that there is a high percentage (70 per cent) of men amongst non-working-age Ukrainian migrants in the UK. The age distribution of working-age migrants from EaP countries is more similar to that of EUA8 migrants than to migrants from other parts of Europe living in the UK. For example, less than 8 per cent of working-age migrants from EaP countries and EUA8 are aged over 50 compared to around a quarter of EU14 migrants and 18 per cent from other parts of Europe. However, EUA8 migrants tend to be even more concentrated within the younger age categories than migrants from $\mathrm{EaP}$ countries due to the large inflows of EUA8 migrants that have arrived in the UK since 2004. Therefore, many of the differences in the age distribution will be strongly affected by the arrival patterns of the migrant groups, which are reported in Table 7.

Table 7 confirms that the majority of migrants from EaP countries and the EUA8 are relatively recent arrivals. In particular, only a very small percentage of migrants from EaP countries and the EUA8 arrived in the UK before 1990, compared to 56 per cent of migrants from EU14 and 42 per cent from other European countries. The bulk of migrants from EaP countries in the sample entered the UK between the early 1990s and mid-2000s, with 39 per cent arriving in the 1990s and 36 per cent between 2000 and 2003. A higher proportion of Ukrainians arrived in the first of these periods, whereas the opposite was the case for migrants from other $\mathrm{EaP}$ countries. This pattern of arrival is consistent with the decline in the inflows of migrants from EaP countries since the introduction of new migration policies in the second half of the 2000s.The heavy concentration of EUA8 migrants arriving 
between 2004 and 2007 is clearly displayed in Table 7, which also reveals that arrivals slowed after recession hit the UK.

In order to examine differences in educational levels between the migrant groups, Table 8 reports the percentage from each group that are observed in particular educational categories. These categories have been constructed from the variable indicating the age that the individual left full-time education, which is available in the LFS. This variable is used because of the difficulty in examining educational qualifications for migrants, since a large proportion would have obtained these in their home countries and so there may not be an equivalent qualification in the host country. As a result, the highest qualification for a high percentage of immigrants in the LFS is "Other". Three main educational categories are defined: low education (left full-time education before the age of 18); medium education (left between the ages of 18 and 20); and high education (left after the age of 20). Similar educational categories have been used by other studies of immigrants in the UK (see Dustmann et al., 2008). Two other categories are also shown in Table 10: percentage with no education, which is very small for each group, and percentage still in education. The latter does vary somewhat between the migrant groups, and, at 12 per cent is highest amongst working-age Ukrainian migrants. This suggests that the student route is an important method of entry for Ukrainians into the UK. Moreover, the percentage of migrants with high levels of education is also highest for Ukrainians, closely followed by migrants from other EaP countries. There is however also a relatively high percentage of the latter group in the low education category, especially in comparison to Ukrainian and EUA8 migrants. The relatively high levels of education displayed by migrants from EaP countries and the EUA8 will be related to age, since younger and more recent migrants tend to be better educated. In addition, this may be partly due to different legal frameworks for migration from European countries, since there is now freedom of movement from the EUA8, as well as from the EU14, whereas migration from outside the European Union is likely to be more skill-biased.

\section{Labour Market Outcomes of European Migrants in the UK}

In this section, the same LFS dataset is used to examine the labour market outcomes of migrants from $\mathrm{EaP}$ countries and these are again compared with the same groups of European migrants that were introduced in the previous section. Migrants from $\mathrm{EaP}$ countries are again split into those who were born in the Ukraine and those born 
in other EaP countries. However, the cell sizes are even smaller than those observed in the previous section because most of the tables in this section just relate to migrants with jobs.

Table 9 provides some basic statistics on labour market outcomes by reporting broad economic activity for each of the groups. The overall employment rate is higher for migrants from EaP countries (63 per cent) than it is for other European migrants. However, the employment rate for migrants from other EaP countries was only 55 per cent, compared with 68 per cent from the Ukraine. All of these employment rates are much lower than those observed for migrants from the European Union, especially from the EUA8. It does not appear as though these differences can be explained by compositional factors, since the employment rate differentials are largely preserved when multivariate statistical analysis is undertaken. In particular, binary regression models which control for differences in gender, age, marital status, year of arrival, education and region across the migrant groups produce a similar pattern and magnitude of employment rate differences to those shown in Table 9.

Unemployment is also relatively high amongst migrants from other $\mathrm{EaP}$ countries, with an unemployment rate (expressed as a percentage of economically active people) of almost 18 per cent. The unemployment rate for Ukrainians in the sample is also in excess of 10 per cent, whereas it is less than 6 per cent for migrants from the European Union and 8.3 per cent for other European migrants. The economic activity rate is also relatively high for migrants from other $\mathrm{EaP}$ countries and other European countries. This is particularly the case for women, since the economic inactivity rate for both groups is in excess of 40 per cent. Drinkwater and Robinson (2011) find that a relatively high percentage of migrants from other European countries (including people born in EaP countries) claim benefits in the UK, especially in comparison to people born in the EUA8 and EU14. This is true for both men and women, with relatively high levels of income support and sickness/ disability claims observed for both sexes. This could be the result of higher levels of discouraged workers following job displacement, whilst the relatively low percentage of benefit claimants amongst EUA8 migrants is likely to have been influenced by the restrictions on access to benefits in the UK by this group following EU enlargement. Drinkwater and Robinson (2011) report that whilst social assistance claims initially increase with years since migration they do so at a decreasing rate 
and there is a varying impact for different migrant groups in the UK. The turning point for the effect of years since migration on social assistance claims is highest for EU14 migrants (29 years in the UK) and amongst the lowest for Other European migrants (9 years in the UK). This is likely to reflect a higher incidence of social assistance claims due to ageing for EU14 migrants, whilst for Other Europeans it may reflect a different mix of origin countries across migrant cohorts.

Details on the occupational attainment of European migrants in the UK are provided in Table 10. EUA8 workers are highly concentrated within low-skilled occupations, with professional and managerial occupations accounting for less than 10 per cent of employment within this group. The occupational distribution is more evenly balanced for the other migrant groups. However, the percentage of Ukrainians working in the UK who are employed in professional and managerial positions is relatively low in comparison to migrants from EU14 and other European countries. Furthermore, almost a half of Ukrainian migrant workers in the sample are employed in low-skilled occupations. This is high but still far lower than the equivalent percentage observed for EUA8 migrants.

Information on the sector of employment is presented for each of the migrant groups in Table 11. This table again reveals some differences between migrants from $\mathrm{EaP}$ countries and the other groups, especially in relation to EUA8 migrants. In particular, there is a noticeably high incidence of employment amongst EUA8 migrants in the production, manufacturing, retail and hospitality, with a relatively low percentage (13 per cent) employed in business services and finance. In contrast, over a quarter of migrant workers from $\mathrm{EaP}$ countries are employed in this sector. This consists of two sections (financial intermediation and real estate, renting and business activities), spanning a total of eight industrial divisions, as detailed in the notes to Table 16. This is a relatively high paying sector, with gross average hourly earnings being over 40 per cent higher than the average earnings of European migrants in the sample of LFS data being examined. The comparatively high proportion of migrants from EaP countries employed in Business Services/ Finance is consistent with their relative clustering in London - the UK's dominant financial centre - as reported in Table 11. The proportion observed in production and manufacturing will be influenced by the absence of some migrant workers from these sectors from the LFS sampling frame because of the higher incidence of short term and irregular employment, implying that the actual percentage of EaP migrants 
employed in these sectors could well be higher. There is also a relatively high proportion of migrants from EaP countries and Other European countries in retail and hospitality. Although public services account for 16 per cent of employment for migrant workers from EaP countries, this is relatively low compared to migrants from EUA8 and other European countries.

The relatively low concentration of migrant workers from EaP countries in the public sector is confirmed by the statistics reported in the bottom row of the table, which show the percentage employed in the public sector. This is highest for EU14 migrants, followed fairly closely by migrants from other European countries. Only 11 per cent of migrants from EaP countries are employed in the public sector, although this is over 4 percentage points higher than the equivalent figure for EUA8 migrants. It should be noted that the sectoral distribution of migrants from the Ukraine and Other EaP countries appears to be fairly similar. The percentage of migrants from EaP countries in production and manufacturing is also relatively low, especially in comparison to EUA8 migrants. Further examination of this category indicates that there are only a few individuals employed in agriculture. The most noticeable difference is the relatively high percentage of migrants from other EaP countries employed in construction, although this may be influenced by the small number of observations for this group of migrants.

\section{Labour Market Impact and Skill Shortages}

A large literature has emerged in recent years on the impact of immigrants on the economy. Overall, immigration can benefit the economy since it usually leads to a rise in GDP. Borjas (1995) introduced the concept of the immigration surplus, which is the gain to natives from immigration. His "back of the envelope" calculations for the United States suggest a basic immigration surplus in the order of 0.1 per cent of GDP. However, the static analysis ignores dynamic considerations - such as increases in human and physical capital accumulation - and the increases in GDP can be much larger when such factors are taken into account (Drinkwater et al., 2007).

However, much of the focus on the economic impact of immigration has centred on the labour market. Despite standard economic theory predicting that immigrants should have a negative effect on the employment and earnings of natives, most studies report that the overall effect is small. ${ }^{16}$ The evidence also indicates this 
to be the case for the UK, although studies have tended to focus on increased overall levels of immigration rather than migration from individual or groups of countries such as EaP countries. Studies such as Dustmann et al. (2005) report that overall there are only very small effects of immigration on the wages and employment of natives. There have also been some studies that have examined the effects of the large population inflows linked to certain events such as post-enlargement migration from EUA8 countries on the UK's labour market. These also typically conclude that the impact, particularly on unemployment, has been very small (Blanchflower et al, 2007; Lemos and Portes, 2008). There may, however, be different effects across the wage distribution, since Dustmann et al. (2008) report that workers in the UK with the highest earnings have actually seen their wages rise as a result of immigration, whereas those in the bottom quintile have seen theirs fall. Therefore, given the very small numbers of migrants from EaP countries, the impact of migrants from these countries on the UK's labour market is likely to have been extremely small. It is also unlikely that increasing levels of immigration from EaP countries will have any significant effect on the overall labour market outcomes of natives and may only affect particular localised areas or demographic groups if the inflows are extremely concentrated in a particular location or sector, which does not appear to be the case from the analysis reported in the previous section.

In addition to small effects on the labour market, immigration to the UK does not appear to have produced any major negative impacts for other aspects of the economy and has also resulted in some positive effects. For example, Frattini (2008) estimates that immigration exerted downward pressure on price growth in service sectors with a high concentration of immigrant workers, although the prices of lowvalue grocery items rose because of increased demand. Gott and Johnston (2002) also suggest that immigrants made a positive net contribution to the economy. They estimated that in 1999-2000, immigrants to the UK contributed $€ 31.2$ billion in taxes and received £28.8bn in benefits and state services. Moreover, Dustmann et al. (2010) argue that the large recent wave of migrants from EUA8 member states made a net positive fiscal contribution, mainly as a result of their very high employment rates. They estimate that the ratio of tax revenues to expenditures for EUA8 migrants to the UK over the period 2005 to 2009 was in the range of 1.3-1.4, compared to 0.80.9 for natives. Furthermore, George et al. (2011) estimate that immigrants impose only small costs on public services in the UK. ${ }^{17}$ Therefore, the UK evidence on these 
issues does not indicate any major negative impact of immigration and again, given the relatively small number of existing and potential migrants from EaP countries, fears of such effects should be further limited. However, the relationship between immigration and aggregate social and economic variables is complex and can vary over time and between regions. Further information can be found in House of Lords (2008), including details of studies that have identified some negative impacts of immigration.

The remainder of this section now focuses on a discussion of current skill needs and shortages in the UK in relation to immigration. Since the introduction of the PBS and the inception of the Migration Advisory Committee (MAC) in 2008, the UK government has taken advice from the MAC on which occupations are in short supply and, therefore, which workers, within particular categories of skill, can enter the UK for job-related reasons. The MAC publishes a "shortage occupation list", reviewed every six months, for Tier 2 of the PBS. The MAC approach is based around the "3 Ss" of "skill, shortage and sensible". More specifically, the MAC seeks first to identify whether an occupation is sufficiently skilled to be on the list. Second, each qualifying occupation is analysed to establish whether there is a shortage of workers doing this job or type of job. Finally, a judgement is reached on whether it is sensible for workers from outside the EEA to enter the UK to fill these positions.

Occupations are based on the 4 digit Standard Occupation Classification (SOC) 2000, although this has to be supplemented by more detailed information in certain cases. To determine levels of skill within occupations, a number of different items of evidence are combined: (i) information on skill levels inherent in the SOC occupation; (ii) levels of formal qualifications among those doing the jobs concerned; (iii) earnings levels, based on the idea that wages reflect marginal productivity and hence the return to investment in education and skills; (iv) the extent of on-the-job training; and (v) innate ability, which may be particularly important for such occupations as artists, performers and sportspeople. Clearly, some of this information can be obtained from national surveys of workers, while other items require more judgemental evaluations. Thus the MAC seeks to combine statistical information drawn from surveys (a "top-down" approach) with qualitative information gathered from consultations with stakeholders in the immigration process such as employers and workers representatives (a "bottom-up" approach). 
In determining whether there are shortages in particular occupations, the MAC also combines top-down and bottom-up approaches. The concept of a labour shortage is operationalized within a simple model of the demand and supply of labour and indicators of shortage include: (i) rapidly rising earnings or high rates of return to education within an occupation; (ii) vacancy and unemployment rates within occupations; and (iii) evidence of employer responses to labour shortages, such as increasing overtime working or payments, increased use of contracting out or increased training expenditure.

Having determined that an occupation is sufficiently skilled and that there is a genuine shortage of workers within that occupation, the MAC must then reach a judgement on whether allowing employers to fill shortages with workers from outside the EEA is the best response to the perceived excess labour demand. Alternatives to importing labour include, inter alia, raising wages to attract existing resident workers, changes to production processes or retraining local workers. The MAC is also required to consider whether filling vacancies with migrant workers is consistent with overall government economic objectives.

Devitt (2012) notes that, in practice, the absence of rigorous quantitative information at occupational level means that the qualitative (bottom-up) criteria often play a key role in the overall decision on whether a particular occupation should be on the shortage list. This has led to criticism that, despite the theoretically rigorous framework set out in MAC (2008), aspects of the process by which the shortage occupation list is assembled are essentially ad hoc.

The introduction of the PBS was explicitly intended to increase the average level of skill amongst non-EEA migrants to the UK. The Home Office noted that the new system "should therefore be focused primarily on bringing in migrants who are highly skilled or to do key jobs that cannot be filled from the domestic labour force or from the EU" (Home Office, 2006: 1). This begs the question of what skills are thought to be in demand and what jobs are "key" to the UK. George et al. (2012) address this question through a variety of methods including statistical analysis of sectoral productivity levels and interviews with employers and employer organisations. Based on the stated objectives of government policy, George et al. define "strategically important skills" to be those which disproportionately contribute to:

- increased productivity growth; 
- higher levels of innovation;

- growth in industries where the UK has a competitive advantage;

- the diffusion of technologies such as ICT which drive growth across a wide range of sectors.

Analysis of data on innovation, productivity and company growth leads to the following list of sectors which are more likely to demand workers with strategically important skills: oil and gas; chemicals and pharmaceuticals; telecommunications; computer services; aerospace manufacturing; architectural and engineering services; and computer, electronic and optical engineering (George et al. 2012: i).

Such an approach, based on an overall vision of what sectors and activities are strategically important for the UK, takes the government perspective on the demand for labour and skills as the main driver of immigration trends. But this neglects the fact that it is the private sector - and not the government - which actually utilises skills in the production process and, hence, is the ultimate source of labour demand and the demand for migrants. It is less the considerations of national strategic interest and more the need to compete and make profits which motivates the employers of migrant labour, and this suggests that employers and their representatives will view a much wider set of skills, occupations and sectors as generating the need to import labour.

Thus, in interviews with employers and employer representatives, George et al. (2012) uncover a more general complaint that the UK does not produce enough highly skilled workers (graduates) in science, technology, engineering and mathematics (STEM) subjects. This is a long-standing criticism of the education system in the UK, which holds across a wide range of types of employer and sector. For example, Clarke (2011) reported that a Confederation of British Industry survey found that 43 per cent of employers thought that increasing the number and quality of STEM graduates was a top priority, rising to 83 per cent for science, engineering and information technology firms. While current government policy on higher education has, to some extent, protected these subjects from an increased level of marketization, it is unlikely that this will do enough to reduce the excess demand for workers with scientific and technical skills, and a considerable role here for migration from outside the EEA will remain.

In addition to formal STEM qualifications, interviews undertaken by George et al. (2012) with employers noted the importance, particularly within the financial 
sector (an area of activity where the UK is thought to have a competitive advantage), of the softer skills that migrant employees can offer. These include the linguistic and cultural skills seen as vital when operating in multinational markets, where knowledge of and sensitivity to business and cultural practices in other countries are important.

It is interesting to compare the actual shortage occupation lists produced by the MAC for Tier 2 migration under the PBS with the strategically important skills identified in the work of George et al. (2012). Examination of the current shortage list, on the UK Border Agency website, suggests that, of the 34 four-digit occupation codes within which employers are currently allowed to recruit from outside the EEA, 16 are those where qualifications in the STEM subjects would be expected. As well as a range of engineering occupations, for example in the nuclear industry, these 16 occupations include secondary teachers of maths, chemistry and physics. Of the remaining 18 occupations, a further six are in the areas of health and social work and five are in the broad area of the arts and design. The remainder of the shortage occupations include jobs as cooks and chefs, or other particular types of skilled, manual occupations which do not require such high levels of formal qualifications as the more STEM-related types of jobs mentioned. Examination of the shortage list suggests that the final outcome of the MAC approach to determining the shortage occupations is influenced as much by narrow, sectoral labour needs as by national, strategic, economic objectives.

It is difficult, given data constraints, to evaluate the extent to which the current allocation of migrants from $\mathrm{EaP}$ countries to sectors, mirrors the shortage occupation list, as this is at a highly disaggregated level. However, Table 11 would suggest that, with high concentrations of workers in retail and hospitality and business services and finance, the vast majority of current migrants from EaP countries are not working in occupations judged by the MAC to have shortages of skilled workers. Of course, this picture reflects, in part, that such workers are in occupations not commensurate with their skill levels and may view labour migration as a temporary state. For those who do remain in the UK, gaining higher skilled jobs will be an ambition.

The institutional framework established by the PBS for migrant labour emphasises that - barring a major change in policy by the UK government - future opportunities for migrants from outside the EEA, including those from EaP 
countries, will primarily be for those in skilled occupations where a strategic or sectoral shortage of skills has been identified. To the extent that a supply of such skills exists in EaP countries, we might expect to see increased migrant flows, with the associated risk of brain-drain effects.

\section{Conclusions}

The key point to emphasize from the analysis undertaken in this study is that the stock of migrants from EaP countries in the UK is very small - both in absolute terms and relative to other migrant groups. The small scale of previous migration to the UK is particularly noticeable when compared to the inflows of migrants from EUA8 counties since European Union enlargement in 2004. However, inflows of migrants from EaP countries have also fallen since changes have been made to immigration policy in the UK brought about by modifications to the SAWS and SBS in 2007 and the introduction of the PBS in 2008.

Migrants from EaP countries have fairly similar characteristics to migrants from EUA8 countries. For example, there is a slight majority of women and a concentration among younger age categories, due to their relatively recent arrival in the UK. There are, however, some differences between the labour market outcomes of migrants from EaP countries and the EUA8. Employment rates are higher for the latter group but they also tend to work in more routine occupations. Migrant workers from EaP countries are less likely to work in higher-skilled jobs than migrants from the EU14 and other parts of Europe, despite having high levels of qualifications. Possible explanations for this relative mismatch include the age structure (which may be accompanied by higher return intentions amongst younger migrants), a lower recognition of less familiar qualifications by employers and relatively weaker language skills. With more time in the UK, however, migrant workers from EaP countries may move up the occupational ladder.

Increased migration from $\mathrm{EaP}$ countries could provide some economic benefits for the UK. These should be greatest if migration between EaP countries and the UK was fully liberalised. This is because employers could take advantage of a larger supply of labour, which is likely to be composed of highly motivated workers. This in turn could have a (small) positive effect on the UK economic growth rate. A fully liberalised migration regime would, however, have the largest impact on native workers in terms of reduced wages and employment, although previous evidence for 
the UK indicates that these effects are small, including for the large flows from the EUA8 after enlargement in 2004. The social consequences of immigration would also be greatest under a fully liberalised regime and the impact on public services within areas experiencing rapid inflows can be relatively acute. The economic benefits to the UK from migration from EaP countries would be more limited under other migration scenarios such as transitional arrangements or sectoral and occupational quotas. However, employers in particular sectors could benefit from bilateral arrangements with EaP countries. This is likely to apply to the agricultural sector, especially as a high percentage of migrant workers on the SAWS and SBS came from EaP countries prior to 2008.

Despite the possible economic benefits of immigration for host economies and that negative economic consequences may be limited for countries such as the UK, it appears that government policy towards non-EEA immigrants will become increasingly strict over the coming years. This is because of negative public opinion, a more anti-immigration stance by the incumbent government and the current problems affecting the economy. Due to the perception amongst the public that there are very large numbers of European migrants in the UK, it is also highly unlikely that the UK government will establish specific arrangements with regards to migration from $\mathrm{EaP}$ countries. Therefore, potential migrants from $\mathrm{EaP}$ countries should target the official entry routes, especially those relating to work and study. There are shortage occupations which could be filled by migrant workers from EaP countries. Details of these occupations are published by the MAC every six months and particularly relate to highly skilled and technical sectors. Therefore, increased migration from EaP countries could occur if suitably qualified individuals were made aware of the available opportunities. Given that entry into such occupations for nonEEA migrants is through the PBS, then migration from non-EEA countries - such as $\mathrm{EaP}$ countries - to the UK will naturally be biased towards younger and more educated workers because of the higher number of points allocated to these applicants. 


\section{References}

Blanchflower, D. and Bell, D. (2010), "UK unemployment in the Great Recession", National Institute Economic Review, R3-R25.

Blanchflower, D., Saleheen, J ., Shadforth, C. (2007), "The impact of recent migration from Eastern Europe on the UK economy", IZA Discussion Paper No. 2615.

Blinder, S. (2011), "UK public opinion toward immigration: Overall attitudes and level of concern", Migration Observatory Briefing Paper, University of Oxford.

Borjas, G.J . (1995), “The economic benefits from immigration”, J ournal of Economic Perspectives, 9(2), 3-22.

Borjas, G.J . (2003), "The labor demand curve is downward sloping: Re-examining the impact of Immigration on the labor market", Quarterly Journal of Economics, 118, 1335-1374.

Clark, K. and Drinkwater, S. (1998), "Ethnicity and self-employment in Britain", Oxford Bulletin of Economics and Statistics, 60, 393-407.

Clarke, S. (2011), "The STEM subject push", Civitas Online Report.

\section{http:// www.civitas.org.uk/pdf/stempush2011.pdf}

Devitt, C. (2012), "Labour migration governance in contemporary Europe. The UK case", Fieri Working Paper.

Drinkwater, S., Levine, P., Lotti, E. and Pearlman, J. (2007), "The immigration surplus revisited in a general equilibrium model with endogenous growth", J ournal of Regional Science, 47, 569-601.

Drinkwater, S., Eade, J . and Garapich, M. (2009), "Poles apart? EU enlargement and the labour market outcomes of Immigrants in the UK", International Migration, 47, 161-90.

Drinkwater, S., Eade, J . and Garapich, M. (2010), “What's behind the figures? An investigation into recent Polish migration to the UK", in R. Black, G. Engbersen, M. Okolski and C. Pantiru (eds), A Continent Moving West? EU Enlargement and Labour Migration from Central and Eastern Europe, Amsterdam University Press, Amsterdam.

Drinkwater, S. and Robinson, C. (2011), "Welfare participation by immigrants in the UK”, IZA Discussion Paper No. 6144.

Dustmann, C., Fabbri, F., Preston, I. (2005), "The impact of immigration on the British labour market”, Economic J ournal, 115, F324-F341. 
Dustmann, C., Frattini, T. and Hills, C. (2010), "Assessing the fiscal costs and benefits of A8 migration to the UK", Fiscal Studies, 31, 1-41.

Dustmann, C., Glitz, A. and Frattini, T. (2008), "The labour market effects of immigration", Oxford Review of Economic Policy, 24, 478-495.

Dustmann, C. and Weiss, Y. (2007), "Return migration: Theory and empirical evidence from the UK", British J ournal of Industrial Relations, 45, 236-256.

Frattini, T. (2008), "Immigration and prices in the UK", Paper presented at the Work and Pensions Economics Group Annual Conference, University of Sheffield, July 2008.

George, A., Meadows, P., Metcalf, H. and Rolfe, H. (2011), "Impact of migration on the consumption of education and children's services and the consumption of health services, social care and social services", Report to the Migration Advisory Committee.

George, A., Lalani, M., Mason, G., Rolfe, H. and Rosazza Bondibene, C. (2012), "Skilled immigration and strategically important skills in the UK economy", Report to the Migration Advisory Committee.

Gott, C. and J ohnston, K. (2002), "The migrant population in the UK: Fiscal effects", Home Office Research, Development and Statistics Occasional Paper No. 77.

Gregg, P. and Wadsworth, J. (2010a), "Employment in the 2008-2009 recession", Economic and Labour Market Review, 4(8), pp. 37-43.

Hatton, T. and Wheatley Price, S. (2005), "Migration, migrants and policy in the United Kingdom" in K. F. Zimmermann (ed.) European Migration: What Do We Know?, Oxford, Oxford University Press.

Home Office (2006), A Points-Based System: Making Migration Work for Britain, HMSO, London

House of Lords (2008), The Economic Impact of Immigration, Select Committee of Economic Affairs, First Report of Session 2007-8, London, The Stationary Office Limited.

Lemos, S. and Portes, J . (2008), "The impact of migration from the new European Union member states on native workers", Department for Work and Pensions Working Paper No. 52.

Longhi, S., Nijkamp, P. and Poot, J . (2010), “Meta-analyses of labour-market impacts of immigration: key conclusions and policy implications", Environment and Planning C: Government and Policy, 28, 819-833. 
MAC (2008), Identifying Skilled Occupations where Migration Can Sensibly Help to Fill Labour Shortages, Migration Advisory Committee.

OECD (2008), Country of Birth Database, Organisation for Economic Cooperation and Development.

ONS (2010), Estimated Population Resident in the United Kingdom, by Foreign Country of Birth, January 2010 - December 2010, Office for National Statistics.

ONS (2012), Employment Levels by Country of Birth and Nationality, Office for National Statistics.

Pollard, N., Latorre, M. and Sriskandarajah, D. (2008), Floodgates or Turnstiles? Post EU Enlargement Migration Flows to (and from) the UK, Institute for Public Policy Research, London.

Salt, J . (2009), "International migration and the United Kingdom”, Report of the United Kingdom SOPEMI Correspondent to the OECD, London. 
Figure 1: Individuals Given Leave to Enter the UK via the Employment Route from EaP Countries, 2004-10

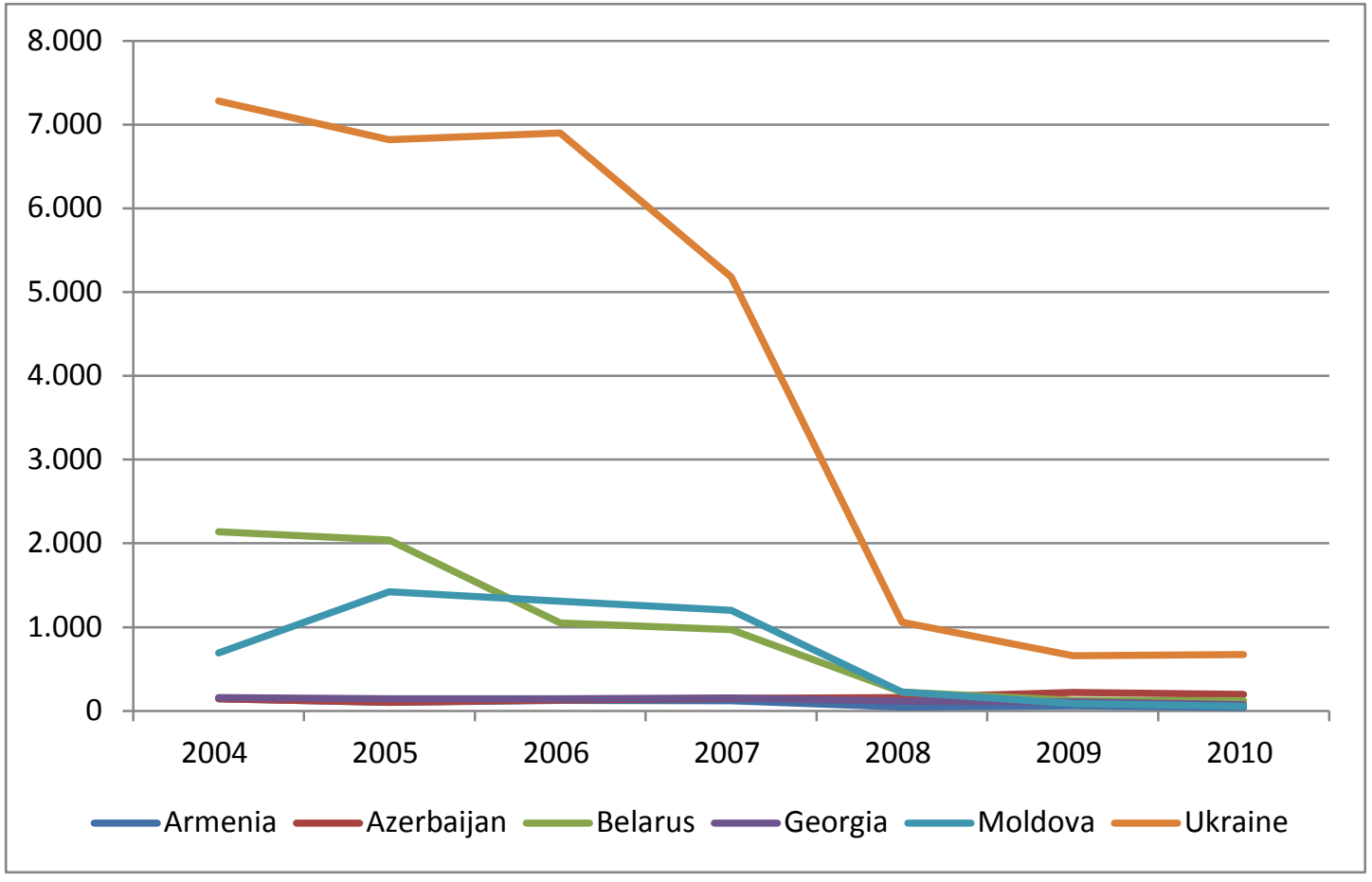

Source: Home Office. 
Figure 2: NINo Registrations by Nationals from EaP Countries, 2002-10

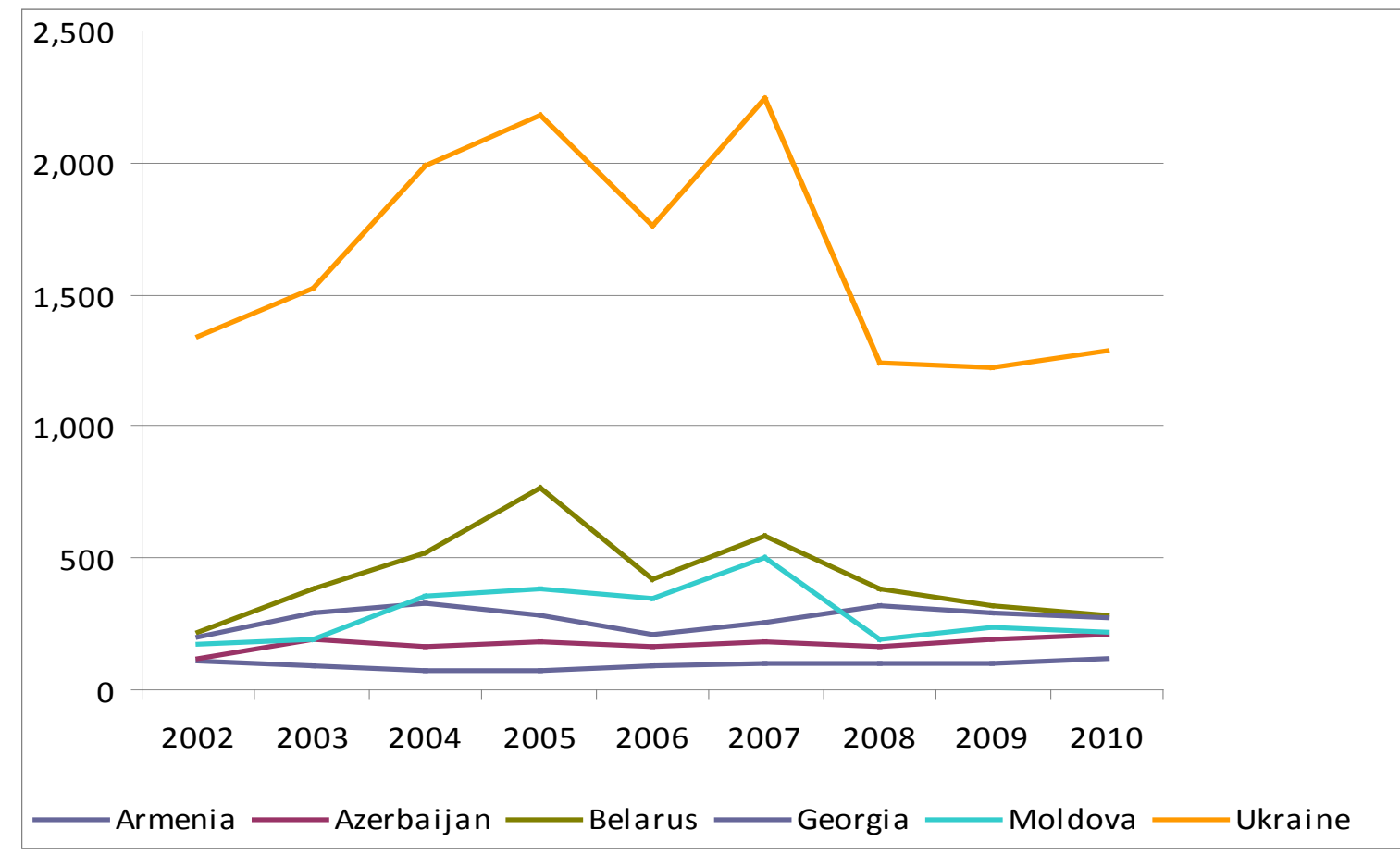

Source: Department for Work and Pensions. 
Table 1: Employment Entrants from EaP Countries to the UK in the Pre-PBS

Period by Category

Work Permits Other

Employment: Dependents

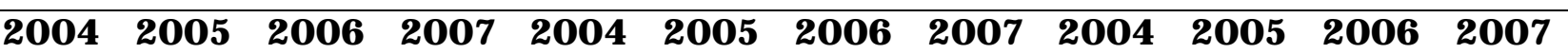

\begin{tabular}{lcccccccccccc}
\hline Armenia & 120 & 75 & 40 & 55 & 10 & 25 & 75 & 55 & 15 & 5 & 10 & 10 \\
Azerbaijan & 80 & 60 & 70 & 70 & 25 & 15 & 35 & 50 & 40 & 25 & 25 & 30 \\
Belarus & 400 & 535 & 185 & 295 & 1,700 & 1,450 & 815 & 625 & 40 & 50 & 50 & 50 \\
Georgia & 70 & 35 & 40 & 35 & 85 & 100 & 100 & 95 & 5 & 10 & 5 & 20 \\
Moldova & 415 & 545 & 375 & 260 & 265 & 845 & 910 & 900 & 10 & 20 & 25 & 35 \\
Ukraine & 2,100 & 2,120 & 1,950 & 1,150 & 5,040 & 4,505 & 4,740 & 3,820 & 140 & 200 & 215 & 210 \\
\hline $\begin{array}{l}\text { All EaP } \\
\text { countries }\end{array}$ & 3,185 & 3,370 & 2,660 & 1,865 & 7,125 & 6,940 & 6,675 & 5,545 & 250 & 310 & 330 & 355
\end{tabular}

Source: Home Office.

Notes: Cells with fewer than 1,000 observations have been rounded to the nearest 5 and numbers greater than 1,000 rounded to three significant figures. Therefore, totals may not add due to rounding. Other work categories include persons entering the UK in the following pre-PBS categories: ministers of religion; postgraduate doctors or dentists; working holidaymakers; seasonal agricultural workers; diplomats, consular officers or persons in foreign and Commonwealth government missions; nurses supervised practice; investors; Highly Skilled Migrant Programme; and au pairs. 
Table 2: Employment Entrants from EaP countries to the UK in the PBS Period by Category

\begin{tabular}{lccccccccc}
\hline & \multicolumn{3}{c}{ PBS Categories } & \multicolumn{3}{c}{$\begin{array}{c}\text { Pre-PBS and Non-PBS } \\
\text { Categories }\end{array}$} & \multicolumn{3}{c}{$\begin{array}{c}\text { Dependents: } \\
\text { Employment and PBS }\end{array}$} \\
\hline & $\mathbf{2 0 0 8}$ & $\mathbf{2 0 0 9}$ & $\mathbf{2 0 1 0}$ & $\mathbf{2 0 0 8}$ & $\mathbf{2 0 0 9}$ & $\mathbf{2 0 1 0}$ & $\mathbf{2 0 0 8}$ & $\mathbf{2 0 0 9}$ & $\mathbf{2 0 1 0}$ \\
\hline Armenia & $*$ & 20 & 30 & 35 & 35 & $*$ & 15 & 10 & 10 \\
Azerbaijan & 5 & 80 & 125 & 115 & 90 & 40 & 40 & 50 & 25 \\
Belarus & 5 & 60 & 75 & 180 & 40 & 15 & 40 & 30 & 30 \\
Georgia & $*$ & 55 & 40 & 90 & 35 & 30 & 20 & 15 & 5 \\
Moldova & 0 & 25 & 35 & 215 & 50 & 15 & 10 & 20 & 0 \\
Ukraine & 20 & 325 & 510 & 910 & 205 & 55 & 135 & 125 & 110 \\
\hline $\begin{array}{l}\text { All EaP } \\
\text { countries }\end{array}$ & 30 & 565 & 815 & 1,545 & 455 & 155 & 260 & 250 & 180 \\
\hline \hline
\end{tabular}

Source: Home Office.

Notes: * denotes that the cell contains 1 or 2 observations. See also notes to Table 1. 
Table 3: NINo Registrations by Overseas Nationals in the UK, 2002-11

\begin{tabular}{ccccc}
\hline & Total & $\begin{array}{c}\text { EaP } \\
\text { countries }\end{array}$ & $\begin{array}{c}\text { Ukraine as \% of } \\
\text { registrations from } \\
\text { EaP countries }\end{array}$ & $\begin{array}{c}\text { Registrations from } \\
\text { EaP countries as \% } \\
\text { of Total }\end{array}$ \\
\hline 2002 & 311,340 & 2,160 & 62.04 & 0.69 \\
2003 & 362,210 & 2,660 & 57.14 & 0.73 \\
2004 & 412,780 & 3,430 & 58.02 & 0.83 \\
2005 & 618,560 & 3,860 & 56.48 & 0.62 \\
2006 & 633,050 & 2,990 & 58.86 & 0.47 \\
2007 & 796,880 & 3,860 & 58.03 & 0.48 \\
2008 & 669,560 & 2,390 & 51.88 & 0.36 \\
2009 & 613,210 & 2,360 & 51.69 & 0.38 \\
2010 & 667,500 & 2,390 & 53.97 & 0.36 \\
$2011^{*}$ & 513,840 & 1,980 & 57.58 & 0.39 \\
\hline $2002-11$ & $5,598,930$ & 28,080 & 56.70 & 0.50 \\
\hline \hline
\end{tabular}

Source: Department for Work and Pensions.

Notes: * denotes that information is only available for first three quarters of 2011. 
Table 4: UK Resident Population, Immigrants and People Born in EaP Countries, 2001

\begin{tabular}{lcc}
\hline \hline & Number & $\begin{array}{c}\text { \% of All } \\
\text { Immigrants }\end{array}$ \\
\hline Armenia & 589 & 0.01 \\
Belarus & 561 & 0.01 \\
Georgia & 1,154 & 0.02 \\
Moldova & 551 & 0.01 \\
Ukraine & 455 & 0.01 \\
\hline All EaP countries & 11,913 & 0.24 \\
\hline Total Immigrants & $4,896,600$ & 0.31 \\
\hline Resident Population & $58,820,242$ & 100.00 \\
\hline
\end{tabular}

Source: Census of Population, ONS. 
Table 5: Gender and Broad Age of Migrants from EaP Countries in the UK (in per cent)

\begin{tabular}{lcccc}
\hline \hline & Male & Working Age & N & $\begin{array}{c}\text { Total Migrants from } \\
\text { EaP countries }\end{array}$ \\
\hline Ukraine & 51.4 & 56.6 & 362 & 72.7 \\
Belarus & 46.2 & 82.1 & 39 & 7.8 \\
Moldova & 50.0 & 92.9 & 28 & 5.6 \\
Armenia/ Azerbaijan/ Georgia & 49.3 & 78.3 & 69 & 13.9 \\
\hline All EaP Migrants & 50.6 & 63.7 & 498 & 100.0 \\
\hline \hline
\end{tabular}

Source: LFS (1999-2011). 
Table 6: Age and Gender of Working-Age Migrants from EaP Countries and Comparison Groups (in per cent)

\begin{tabular}{lccccc}
\hline \hline & Ukraine & $\begin{array}{c}\text { Other EaP } \\
\text { countries }\end{array}$ & EUA8 & EU14 & Other Europe \\
\hline Male & 37.6 & 45.5 & 46.9 & 46.7 & 48.7 \\
\hline Aged 16-24 & 21.0 & 18.8 & 22.5 & 14.1 & 15.4 \\
Aged 25-34 & 38.1 & 44.6 & 49.2 & 27.0 & 27.9 \\
Aged 35-49 & 34.2 & 30.4 & 20.6 & 34.4 & 39.1 \\
Aged 50-64 & 6.8 & 6.3 & 7.7 & 24.4 & 17.6 \\
\hline $\mathrm{N}$ & 205 & 112 & 6,254 & 16,457 & 6,135 \\
\hline \hline
\end{tabular}

Source: LFS (1999-2011). 
Table 7: Time of Arrival for Working-Age Migrants from EaP Countries and Comparison Groups (in per cent)

\begin{tabular}{lccccc}
\hline \hline & Ukraine & $\begin{array}{c}\text { Other EaP } \\
\text { countries }\end{array}$ & EU-A8 & EU14 & $\begin{array}{c}\text { Other } \\
\text { Europe }\end{array}$ \\
\hline Arriving before 1990 & 2.0 & 0.9 & 6.2 & 55.9 & 41.7 \\
Arriving in 1990s & 45.6 & 27.9 & 10.2 & 25.2 & 31.2 \\
Arriving 2000-3 & 30.4 & 45.1 & 13.0 & 10.2 & 14.3 \\
Arriving 2004-7 & 18.1 & 17.1 & 61.2 & 6.8 & 9.0 \\
Arriving 2008-11 & 3.9 & 9.0 & 9.4 & 1.9 & 3.9 \\
\hline $\mathrm{N}$ & 204 & 111 & 6214 & 16264 & 6073 \\
\hline \hline
\end{tabular}

Source: LFS (1999-2011). 
Table 8: Educational Category of Working-Age Migrants from EaP Countries and Comparison Groups (in per cent)

\begin{tabular}{lccccc}
\hline \hline & Ukraine & $\begin{array}{c}\text { Other EaP } \\
\text { countries }\end{array}$ & EUA8 & EU14 & $\begin{array}{c}\text { Other } \\
\text { Europe }\end{array}$ \\
\hline No Education & 1.0 & 0.9 & 0.6 & 0.3 & 1.5 \\
Low Education & 18.7 & 28.7 & 16.0 & 41.4 & 41.6 \\
Medium Education & 14.7 & 16.7 & 44.4 & 21.5 & 23.3 \\
High Education & 53.5 & 50.0 & 34.8 & 29.9 & 26.3 \\
Still in Education & 12.1 & 3.7 & 4.3 & 7.0 & 7.2 \\
\hline $\mathrm{N}$ & 198 & 104 & 6,094 & 16,254 & 5,594 \\
\hline \hline
\end{tabular}

Source: LFS (1999-2011). 
Table 9: Economic Activity of Working-Age Migrants from EaP Countries and Comparison Groups (in per cent)

\begin{tabular}{lccccc}
\hline \hline & Ukraine & $\begin{array}{c}\text { Other EaP } \\
\text { countries }\end{array}$ & EUA8 & EU14 & $\begin{array}{c}\text { Other } \\
\text { Europe }\end{array}$ \\
\hline Employed & 67.8 & 54.5 & 78.8 & 72.1 & 59.6 \\
Unemployed & 7.8 & 11.6 & 4.9 & 4.3 & 5.4 \\
Inactive & 24.4 & 33.9 & 16.3 & 23.6 & 34.9 \\
\hline $\mathrm{N}$ & 205 & 112 & 6,254 & 16,457 & 6,135 \\
\hline
\end{tabular}

Source: LFS (1999-2011). 
Table 10: Occupation of Working-Age Migrants from EaP Countries and Comparison Groups (in per cent)

\begin{tabular}{lccccc}
\hline \hline & Ukraine & $\begin{array}{c}\text { Other EaP } \\
\text { countries }\end{array}$ & EUA8 & EU14 & $\begin{array}{c}\text { Other } \\
\text { Europe }\end{array}$ \\
\hline Professional/Managerial & 21.7 & 40.0 & 9.4 & 35.4 & 30.0 \\
Intermediate Occupations & 31.2 & 30.0 & 25.1 & 33.5 & 33.8 \\
Low-Skilled Occupations & 47.1 & 30.0 & 65.5 & 31.2 & 36.2 \\
\hline $\mathrm{N}$ & 138 & 60 & 4893 & 11636 & 3594 \\
\hline \hline
\end{tabular}

Source: LFS (1999-2011). 
Table 11: Sector of Employment for Working-Age Migrants from EaP

Countries and Comparison Groups (in per cent)

\begin{tabular}{lccccc}
\hline \hline & Ukraine & $\begin{array}{c}\text { Other EaP } \\
\text { countries }\end{array}$ & EUA8 & EU14 & $\begin{array}{c}\text { Other } \\
\text { Europe }\end{array}$ \\
\hline Production/ Manufacturing & 13.7 & 11.5 & 26.5 & 14.3 & 12.1 \\
Construction & 6.5 & 16.4 & 9.2 & 6.0 & 9.1 \\
Retail/Hospitality & 28.8 & 21.3 & 25.7 & 19.7 & 25.3 \\
Transport/Communications & 2.9 & 4.9 & 8.6 & 6.4 & 6.4 \\
Business Services/ Finance & 24.5 & 27.9 & 12.6 & 19.3 & 17.8 \\
Public Services & 15.8 & 16.4 & 11.5 & 27.8 & 22.9 \\
Other Services & 7.9 & 1.6 & 6.1 & 6.4 & 6.5 \\
\hline Public Sector & 10.1 & 13.1 & 6.6 & 22.1 & 18.4 \\
\hline $\mathrm{N}$ & 139 & 61 & 5,238 & 1,2580 & 3,992 \\
\hline \hline
\end{tabular}

Source: LFS (1999-2011).

Notes: Business Services/Finance consists of the following industrial divisions: financial intermediation, excluding insurance and pensions funding; insurance and pension funding, except compulsory social security; activities auxiliary to financial intermediation; real estate activities; renting of machinery and equipment without operator and of personal and household goods; computer and related activities; research \& development; and other business services. 
APPENDIX

Table A1: Passengers Given Leave to Enter the UK from EaP Countries, 2004-10

\begin{tabular}{|c|c|c|c|c|c|c|c|c|}
\hline & 2004 & 2005 & 2006 & 2007 & 2008 & 2009 & 2010 & 2004-10 \\
\hline Armenia & 3,480 & 2,540 & 2,640 & 3,250 & 3,030 & 3,280 & 3,900 & 22,120 \\
\hline Azerbaijan & 7,100 & 8,450 & 9,100 & 9,700 & 9,430 & 10,900 & 11,400 & 66,080 \\
\hline Belarus & 13,000 & 15,500 & 16,200 & 16,500 & 16,800 & 16,600 & 16,400 & 111,000 \\
\hline Georgia & 5,410 & 6,380 & 7,350 & 7,780 & 8,760 & 9,100 & 9,190 & 53,970 \\
\hline Moldova & 3,920 & 5,190 & 5,410 & 4,730 & 4,070 & 3,810 & 3,760 & 30,890 \\
\hline Ukraine & 53,300 & 57,000 & 67,200 & 69,500 & 68,500 & 72,400 & 75,500 & 463,400 \\
\hline $\begin{array}{l}\text { All EaP } \\
\text { Countries }\end{array}$ & 86,210 & 95,060 & 107,900 & 111,460 & 110,590 & 116,090 & 120,150 & 747,460 \\
\hline Total Passengers & $12,000,000$ & $11,800,000$ & $12,900,000$ & $12,800,000$ & $12,400,000$ & $12,300,000$ & $12,500,000$ & $86,700,000$ \\
\hline EaP as \% of total & 0.7 & 0.8 & 0.8 & 0.9 & 0.9 & 0.9 & 1.0 & 0.9 \\
\hline
\end{tabular}

Source: Home Office.

Notes: Cells with fewer than 1,000 observations have been rounded to the nearest 5 and numbers greater than 1,000 rounded to three significant figures. Therefore, totals may not add due to rounding. 
Table A2: Passengers Given Leave to Enter the UK from EaP countries by Route, 200410

\begin{tabular}{|c|c|c|c|c|c|c|c|c|}
\hline & 2004 & 2005 & 2006 & 2007 & 2008 & 2009 & 2010 & 2004-10 \\
\hline & \multicolumn{8}{|c|}{ Employment } \\
\hline Armenia & 145 & 100 & 125 & 120 & 45 & 60 & 40 & 635 \\
\hline Azerbaijan & 145 & 100 & 130 & 150 & 160 & 220 & 195 & 1,100 \\
\hline Belarus & 2,140 & 2,040 & 1,050 & 970 & 225 & 125 & 120 & 6,670 \\
\hline Georgia & 160 & 145 & 145 & 155 & 115 & 105 & 75 & 900 \\
\hline Moldova & 690 & 1,420 & 1,310 & 1,200 & 225 & 90 & 55 & 4,990 \\
\hline Ukraine & 7,280 & 6,820 & 6,900 & 5,180 & 1,060 & 660 & 675 & 28,575 \\
\hline All EaP countries & 10,560 & 10,625 & 9,660 & 7,775 & 1,830 & 1,260 & 1,160 & 42,870 \\
\hline All countries & 233,000 & 237,000 & 235,000 & 204,000 & 183,000 & 161,000 & 163,000 & $1,416,000$ \\
\hline \multirow[t]{2}{*}{ EaP countries as \% of total } & 4.5 & 4.5 & 4.1 & 3.8 & 1.0 & 0.8 & 0.7 & 3.0 \\
\hline & \multicolumn{8}{|c|}{ Study } \\
\hline Armenia & 95 & 160 & 195 & 150 & 175 & 215 & 285 & 1,275 \\
\hline Azerbaijan & 420 & 405 & 545 & 550 & 555 & 655 & 765 & 3,895 \\
\hline Belarus & 525 & 650 & 755 & 895 & 535 & 445 & 475 & 4,280 \\
\hline Georgia & 585 & 470 & 710 & 755 & 775 & 755 & 715 & 4,765 \\
\hline Moldova & 245 & 210 & 220 & 115 & 130 & 140 & 140 & 1,200 \\
\hline Ukraine & 1,850 & 1,480 & 2,360 & 2,340 & 2,550 & 2,320 & 2,580 & 15,480 \\
\hline All EaP countries & 3,720 & 3,375 & 4,785 & 4,805 & 4,720 & 4,530 & 4,960 & 30,895 \\
\hline All countries & 307,000 & 297,000 & 326,000 & 367,000 & 384,000 & 489,000 & 535,000 & $2,705,000$ \\
\hline \multirow[t]{2}{*}{ EaP countries as \% of total } & 1.2 & 1.1 & 1.5 & 1.3 & 1.2 & 0.9 & 0.9 & 1.1 \\
\hline & \multicolumn{8}{|c|}{ Family } \\
\hline Armenia & 10 & 10 & 15 & 15 & 10 & 15 & 15 & 90 \\
\hline Azerbaijan & 30 & 45 & 50 & 45 & 45 & 40 & 40 & 295 \\
\hline Belarus & 55 & 90 & 85 & 95 & 80 & 60 & 50 & 515 \\
\hline Georgia & 20 & 20 & 30 & 30 & 35 & 30 & 25 & 190 \\
\hline Moldova & 30 & 45 & 60 & 25 & 20 & 30 & 30 & 240 \\
\hline Ukraine & 335 & 385 & 495 & 420 & 365 & 310 & 275 & 2,585 \\
\hline All EaP countries & 480 & 595 & 735 & 630 & 555 & 485 & 435 & 3,915 \\
\hline All countries & 39,700 & 46,300 & 53,300 & 52,600 & 45,400 & 36,600 & 37,300 & 311,200 \\
\hline \multirow[t]{2}{*}{ EaP countries as \% of total } & 1.2 & 1.3 & 1.4 & 1.2 & 1.2 & 1.3 & 1.2 & 1.3 \\
\hline & \multicolumn{8}{|c|}{ Other } \\
\hline Armenia & 3,230 & 2,270 & 2,300 & 2,960 & 2,800 & 2,990 & 3,560 & 20,110 \\
\hline Azerbaijan & 6,510 & 7,900 & 8,370 & 8,950 & 8,670 & 9,960 & 10,400 & 60,760 \\
\hline Belarus & 10,300 & 12,700 & 14,300 & 14,500 & 15,900 & 16,000 & 15,800 & 99,500 \\
\hline Georgia & 4,640 & 5,750 & 6,470 & 6,840 & 7,830 & 8,210 & 8,370 & 48,110 \\
\hline Moldova & 2,950 & 3,520 & 3,820 & 3,400 & 3,690 & 3,540 & 3,530 & 24,450 \\
\hline Ukraine & 43,900 & 48,300 & 57,400 & 61,600 & 64,500 & 69,100 & 72,000 & 416,800 \\
\hline All EaP countries & 71,530 & 80,440 & 92,660 & 98,250 & 103,390 & 109,800 & 113,660 & 669,730 \\
\hline All countries & $11,500,000$ & $11,300,000$ & $12,200,000$ & $12,100,000$ & $11,800,000$ & $11,600,000$ & $11,800,000$ & $82,300,000$ \\
\hline EaP countries as \% of All & 0.6 & 0.7 & 0.8 & 0.8 & 0.9 & 0.9 & 1.0 & 0.8 \\
\hline
\end{tabular}

Source: Home Office. 
Table A3: Employment Entrants from EaP countries to the UK in the PBS Period by Pre-PBS Work Category

\begin{tabular}{|c|c|c|c|c|c|c|c|c|c|}
\hline & \multicolumn{3}{|c|}{ Work Permits } & \multicolumn{3}{|c|}{ Other } & \multicolumn{3}{|c|}{$\begin{array}{l}\text { Dependents: } \\
\text { Employment }\end{array}$} \\
\hline & 2008 & 2009 & 2010 & 2008 & 2009 & 2010 & 2008 & 2009 & 2010 \\
\hline Armenia & 30 & $*$ & 0 & 5 & 30 & 0 & 10 & 5 & 10 \\
\hline Azerbaijan & 70 & 10 & 0 & 45 & 75 & 45 & 40 & 50 & 25 \\
\hline Belarus & 145 & 10 & $*$ & 35 & 25 & 15 & 40 & 25 & 30 \\
\hline Georgia & 75 & 5 & 0 & 15 & 30 & 30 & 20 & 15 & 5 \\
\hline Moldova & 205 & 35 & $*$ & 10 & 10 & 15 & 10 & 20 & $*$ \\
\hline Ukraine & 835 & 135 & 10 & 75 & 70 & 45 & 135 & 130 & 105 \\
\hline $\begin{array}{l}\text { All EaP } \\
\text { Countries }\end{array}$ & 1,360 & 195 & 10 & 185 & 240 & 150 & 255 & 245 & 175 \\
\hline
\end{tabular}

Source: Home Office.

Notes: * denotes that the cell contains 1 or 2 observations. Also see notes to Table A1.

Table A4: Employment Entrants from EaP countries to the UK in the PBS Period by PBS Work Category

\begin{tabular}{lccccccccc}
\hline & & Tier 1 & \multicolumn{3}{c}{ Tier 2 } & \multicolumn{3}{c}{ Tier 5 } \\
& $\mathbf{2 0 0 8}$ & $\mathbf{2 0 0 9}$ & $\mathbf{2 0 1 0}$ & $\mathbf{2 0 0 8}$ & $\mathbf{2 0 0 9}$ & $\mathbf{2 0 1 0}$ & $\mathbf{2 0 0 8}$ & $\mathbf{2 0 0 9}$ & $\mathbf{2 0 1 0}$ \\
\hline Armenia & $*$ & 10 & 10 & 0 & $*$ & 5 & 0 & 10 & 15 \\
Azerbaijan & 5 & 45 & 40 & 0 & 20 & 65 & 0 & 15 & 20 \\
Belarus & 5 & 20 & 15 & 0 & 10 & 30 & 0 & 30 & 30 \\
Georgia & $*$ & 15 & 15 & 0 & 15 & 10 & 0 & 25 & 15 \\
Moldova & 0 & 15 & 5 & 0 & $*$ & 20 & 0 & 10 & 15 \\
Ukraine & 20 & 90 & 100 & 0 & 85 & 165 & 0 & 145 & 245 \\
\hline $\begin{array}{l}\text { All EaP } \\
\text { Countries }\end{array}$ & 30 & 195 & 185 & 0 & 130 & 295 & 0 & 235 & 340 \\
\hline \hline
\end{tabular}

Source: Home Office.

Notes: *denotes that the cell contains 1 or 2 observations. Tier 1 relates to highly skilled migrants, Tier 2 to skilled workers and Tier 5 to temporary workers and youth mobility. Also see notes to Table A1. 
${ }^{1}$ NINo registrations should provide a relative accurate indication of the number of migrant workers coming to work in the UK for the first time since they are obtained from an administrative database maintained by the Department for Work and Pensions. Further information on this data source is provided later in Sections 1 and 2.

2 In contrast, the percentage of NINo registrations accounted for by individuals from Asia and the Middle East fell from 32 per cent to 20 per cent over the same period, whilst the percentage of registrations accounted for by Africans declined from 19 per cent to 8 per cent.

3 EUA8 migrant workers were required to register on the Worker Registration Scheme within one month of taking up employment in the UK. However, it is estimated that a fairly high percentage of workers who should have registered failed to do so. See Drinkwater et al. (2009) for details. Much tighter restrictions were put in place for Bulgarian and Romanian migrants wishing to work in the UK, after these countries joined the European Union in 2007.

${ }^{4}$ In 2007, the overall quota for the SAWS was 16,250. Of this amount, 40 per cent was reserved for Bulgarians and Romanians and the remaining 60 per cent was filled by students from non-EEA countries. The SAWS and SBS became reserved just for workers from Bulgaria and Romania from January 2008. Salt (2009) reports that there were a small number of workers from Ukraine (61) and Moldova (9) on the SAWS in 2008. This compared with 10,850 Bulgarians and 5,674 Romanians in that year.

5 While technically the economy avoided a "double dip" recession, growth remained very sluggish through 2012.

${ }^{6}$ These figures are consistent with those reported for the SAWS and SBS by Salt (2009).

7 Different national statistical agencies carry out the Census in England and Wales, Scotland and Northern Ireland. This sometimes means some variations in the questions asked and also the need to aggregate responses together to obtain figures for the United Kingdom.

8 In particular, Table ST015 contains details on country of birth (for countries with larger resident populations in the United Kingdom), and also enables a limited breakdown by characteristics for gender, age group and area of residence.

9 The enhanced sample roughly doubles the main LFS sample. The boosts to the LFS vary across the United Kingdom and range from around 80 per cent in Wales, which has a relatively small population of immigrants, to no boost at all in Northern Ireland. The boost in London is around 40 per cent. The APS and LFS are also likely to under-sample migrants who have arrived recently in the UK (Drinkwater et al., 2009).

10 This certainly contrasts with the situation for EUA8 migrants since the number of people born in Poland (Lithuania) was estimated to be 532,000 $(87,000)$ in 2010 , compared to fewer than 61,000 $(5,000)$ in 2001.

11 These estimates are, however, based on a small number of observations from the APS source data file.

${ }^{12}$ People born in Armenia, Azerbaijan and Georgia have been combined into a single category because of the coding the country of birth variable in the LFS from 1999 to 2007. These countries are separately identifiable from 2007 onwards but the number of observations is very small for each country ( 7,9 and 9 respectively).

${ }^{13}$ For 1999, however, respondents in their fifth wave of interview are also included, which provides a slight boost to the sample.

${ }^{14}$ More detailed information on age differences is included in Table 6.

15 The EU14 countries are Austria, Belgium, Denmark, Finland, France, Germany, Greece, Ireland, Italy, Luxembourg, Netherlands, Portugal, Spain and Sweden.

${ }^{16}$ See Longhi et al. (2010) for a recent summary. Some studies do find larger effects such as Borjas (2003), who estimates that a 10 per cent increase in immigration leads to a 3-4 per cent fall in the wages of competing natives in the United States. However, this finding is rather an exception within the empirical literature on the labour market impact of immigration (Dustmann et al., 2008).

${ }_{17}$ The public services they focus on are state education, health, social services and social care. 